\title{
The Entrepreneurship and Social Responsibility in Business Market - a Qualitative Analysis
}

\author{
Bogdan FLEACA $\breve{A}^{\left.1^{*}\right)}$, Elena FLEAC $\breve{A}^{1)}$, Andreea DUMITRESCU ${ }^{1)}$ \\ 1) Faculty of Entrepreneurship, Business Engineering and Management, University POLITEHNICA of \\ Bucharest, Romania, 313 Splaiul Independentei, 060042, Bucharest, Romania. \\ ${ }^{*}$ Corresponding author, e-mail: bogdan.fleaca@upb.ro
}

Bulletin UASVM Horticulture 71(2) / 2014

Print ISSN 1843-5254, Electronic ISSN 1843-5394

DOI:10.15835/buasvmcn-hort:10371

\begin{abstract}
The paper aims to explore the entrepreneurship concept and gain deeper understanding of the social responsibility insights with respect to their implications into the business market. The methodological approach comprised a qualitative analysis of the concepts in order to structure and understand knowledge about the key factors encapsulated in the entrepreneurial thinking. Secondly, it has been analyzed the seven core principles of social responsibility that allowed authors to ascertain the main similarities and differences between the two concepts. It has been proposed an integrative model that enables the conceptualization of the relationship arisen from responsibility of the businesses to act and behave in a way that contribute to a sustainable development of the society. The model depicts the entrepreneurial thinking as being firmly embedded in the social responsibility concept that carefully incorporates, in a coherently whole, the responsibilities of the organization to society and the environment, by summing up and addressing different people goals. In the pursuit of their objectives, people appeal to entrepreneurial thinking and the social responsibility creates the framework that guides their actions, becoming aware of the impacts of their decisions and activities on the business market, the society and the environment. The authors emphasized the interdependence between entrepreneurship and social responsibility within the business market. Addressing social, economic and environmental aspects in an integrated manner is expected to be achieved with the aid of entrepreneurial thinking (sense of initiative) of decision makers and key actors towards creating the eco-innovation system on the long run.
\end{abstract}

Keywords: entrepreneurship thinking, social responsibility awareness, sustainable business growth

\section{INTRODUCTION}

The cornerstone of business markets relies on entrepreneurship phenomenon that determines the economic growth of any society. The McClelland\$s work on need of achievement concept firstly analyzed and explained the entrepreneurship thinking. He defined the entrepreneur as the person with high need of achievement, willing to take actions by assuming moderate risks. The researcher highlighted that these psychological characteristics of an entrepreneur could be culturally acquired through education and experience (McClelland, 1967).

Casson (1982) argued that the entrepreneur is a person who takes action and decision about the coordination of scarce resources, and the results depend on the way in which the economic system adjusts to change. The core of this economic theory refers to the aim of entrepreneurs to maximize the profit obtained from a given amount of effort. Moreover, regardless of the economic system (capitalism, socialism, or democracy), the entrepreneurial behavior relies on the profit to buy the consumption of goods and leisure, and the status reflected by the respect from other people.

It is useful to mention the means of a wide range of studies aimed to analyze the entrepreneurship phenomenon at individual, organizational, and societal level. Van de Ven et. all (1984) studied the variables which ensure the success at different levels, as follows: 
a) entrepreneurial level, related to individual, is influenced by education and experience, internal locus of control, risk reduction, and a broad and clear business idea;

b) organizational level is impacted by planning activities, incremental expansion, unit of command, and top management involvement;

c) ecological level, industry as a whole, is influenced by the assistance from a corporate sponsor in terms of equity capital, training, or guaranteed contracts.

The numerous variables encapsulated in entrepreneurial behavior such as individual and contextual factors, and the different levels of analysis (individual, organizational, and social) point out the complexity of the entrepreneurship phenomenon. As Shane (2003) stated, the conceptual framework to understand entrepreneurship required an interdisciplinary approach of psychology, sociology and economics because all of them provide insights, but none can explain the phenomenon completely.

Undoubtedly, the business activities pervade all cultures and societies because of the influence on individual and collective well-being. A body of scientific literature was dedicated to entrepreneurship concept being clearly justified by the growing reality that the creation of new enterprises is critical for economic growth. The studies pointed out the increasing pressure on businesses to be more responsible for the environment and to develop the sustainable businesses practices comprised of social obligation, social reaction, and social responsiveness. Stated otherwise, to serve markets effectively means to bring goods to market as efficiently as possible, to change the business behaviour towards more environmentally friendly practices, and to lead social causes and be on the forefront of the positive changes (Duening et. all, 2010).

In recent times, the long-term business challenges as globalization, pressure on resources and ageing intensify become the key barriers which have to be successfully overcome to ensure the future market economy. Under these conditions, Romania is facing with significant country-specific issues such as administrative capacity, product market reform, the business environment, labor markets, and so on. In addition, the poor quality of regulations and the lack of transparency and predictability of the regulatory framework hinder citizens and businesses creation.

Therefore, Romania, as a European Union member state, has to pay attention to the actual and future economic circumstances of European marketplace. The scientists, researchers and political factors are investing substantial efforts to create a well-functioning and well-connected business markets across European countries, where competition and consumer access can stimulate growth and innovation.

The current study "How companies influence our society: Citizen View" brought to light that the European citizens viewed job creation to be the most positive influence companies have on society (57\%), followed by economic growth (32\%) and providing training to employees (31\%) (European Commission, 2013).

Looking at the economic growth and job creation that can sustain the growing trends of the future marketplace, it is worth mentioning their deeper connection to the entrepreneurial thinking of the citizens. In this view, the Directorate-General "Enterprise and Industry" from the European Commission has been interested in studying the entrepreneurship development in the EU Member states. The study "Entrepreneurship in the EU and beyond" highlighted the most popular reasons for wanting to become an entrepreneur such as personal independence or self-fulfillment $(62 \%$ of respondents), followed by the freedom to choose the place and time to work (30\%), and better income prospects $(16 \%)$. Worthy mentioning, almost a half of respondents (47\%) agreed that the school education helped them to understand the role of entrepreneurs on society by developing a sense of initiative and a sort of entrepreneurial attitude (European Commission, 2012).

Interestingly, the same study revealed the perception of entrepreneurship as an enabler for job creation ( $87 \%$ of respondents) and for creating new products and services from which all of us benefit (78\%). However, due to the current economic climate, the risk of failure and its consequences, and the lack of skills needed to be self - employed, the European respondents were most likely to avoid the entrepreneurial role and to consider selfemployment as a non-feasibility option for the near future (European Commission, 2012).

To address these challenges, the European Union has taken initiative and designed the Europe 
2020 strategy as a framework to encourage the entrepreneurial initiatives and unlock the growth potential of businesses and citizens. The European 2020 strategy for smart, sustainable and inclusive growth has defined the entrepreneurship and innovation as flagship concepts for stimulating the smart development of the society, at large (European Commission, 2010).

As for the smart development, the ISO 26000 (2010) standard tackled an integrated view of the economic, social and environmental considerations by defining the concept of sustainable development. Because the economic, social and environmental goals are common to all people, the smart development or sustainable development has been viewed as a way of summing up the broader expectations of society that needed to be taken into account by companies around the world.

Hence, the awareness of ethical behavior of people, the social responsibility of business coupled with good organizational performance, and the mechanisms and factors that trigger entrepreneurial thinking become substantial concepts that need to be properly analyzed and understood, since they are affecting both business market and peopleфs life.

Based on these circumstances, the paper aims to explore the entrepreneurship concept and the essential role of social responsibility principles in assuming a sustainable entrepreneurial behavior. The research objectives were firstly consisted of a comparative analysis of entrepreneurship and social responsibility concepts and, secondly, of modeling the relation between the entrepreneurship and social responsibility, in business market.

\section{MATERIALS AND METHODS}

In order to fulfill the paper objectives, the research was conducted based on the following qualitative research methods:

1. Exploratory research on applicable studies and regulations to decipher the key factors encapsulated in the entrepreneurial thinking.

2. Qualitative analysis of relevant documents and standards related to social responsibility behavior that underpins its substantial role in business creation.

3. Comparative analysis of the entrepreneurship and social responsibility concepts based on different criteria.
4. Conceptualization of the relationship between the entrepreneurial behavior and social responsibility way of conduct.

According to the European reference framework "Key Competences for Life Long Learning - a European Framework", the entrepreneurship and sense of initiative are interchangeably concepts because both of them are referring to the individual's ability to turn ideas into actions. Being one of the eight key competences for lifelong learning, the entrepreneurial attitude is perceived as a relevant factor for European Union innovation, productivity and competitiveness since it incorporates creativity, innovation and risk taking, as well as the ability to plan and manage projects in order to achieve personal or professional objective (Council Recommendation 394, 2006).

The same source pinpointed the importance of ethical and good governance values of the entrepreneurial thinking, since these support individuals not only in the every day's activities, but also in the workplace, making people more aware of the context of their work and improving their abilities to seize opportunities (Council Recommendation 394, 2006).

Considering the scientific researches, the scholars defined a mix of three factors that assures the entrepreneurial thinking of individuals: knowledge, skills, and attitudes (Matlay, $2005,2006)$. As argued by the studies, fulfilling personal or professional goals with the aid of entrepreneurial thinking requires specific processes such as intention, opportunity search and discovery, decision to exploit opportunity and, finally, exploitation of opportunity. In fact, these phases are pertaining to the "life cycle" concept applied on entrepreneurship that starts with the phase of defining the goal, followed by searching opportunities, taking actions to fruitfully exploit the challenge, and finishes with the commitment of making things happen.

To investigate the key factors encapsulated in the entrepreneurship concept, the study "Effects and impact of entrepreneurship program in higher education", developed by the DirectorateGeneral for "Enterprise and Industry" from European Commission, has defined and assessed the impact of entrepreneurship education by surveying university alumni who participated in 
entrepreneurship programs, as well as surveying a comparable control group consisting of alumni that have not participated in entrepreneurship (European Commission,2012).As entrepreneurship education is based on preparing people to become responsible, the study underpinned that the knowledge, skills and attitudes all together make up the entrepreneurship competence. In this regard, table 1 takes a synoptic view of the abovementioned factors.

In other words, to fully develop the individual's potential, it is required a deeper understanding of entrepreneurt roles in modern economies and societies, having an attitudinal approach rather than a set of personal traits, and unlocking the inner potential by taking actions for fulfilling the careers and personal goals. Undoubtedly, the sense of initiative/entrepreneurial thinking has multiple bounds on humans' creativity and innovation. This assures a stronger focus on consumers' needs and market opportunities, and helps address the current societal challenges.
To further ascertain the concept of entrepreneurship, it is worth to note that by being proactively focused and by taking actions to fruitfully exploit the opportunities, the entrepreneurs are expected to have a strong awareness of social responsibility of their actions, otherwise the business consequences in the marketplace will not be sustainable. In this regard, the concept of social responsibility is highly relevant for entrepreneurs' behavior.

Looking at the key initiatives of international bodies in terms of social responsibility, the act „A renewed EU strategy 2011-14 for Corporate Social Responsibility" has outlined the strategic relevance of the concept thanks to its benefits in terms of risk management, customer relationships, human resource management, and innovation capacity. By adopting a social responsibility behavior, enterprises and entrepreneurs build long-term stakeholders $\$$ trust as a basis for sustainable business models (European Commission, 2011).

To guide the progress, the Commission promoted a new and broader definition by which the

Tab. 1. The key pillars of entrepreneurial thinking, after Council Recommendation 394 (2006)

\begin{tabular}{lll}
\hline Pillar & Meaning & Operational aspects \\
\hline Knowledge & $\begin{array}{l}\text { The need of having a broad } \\
\text { understanding and knowledge of } \\
\text { entrepreneurship }\end{array}$ & $\begin{array}{l}\text { Capacity to seize the challenges and opportunities for } \\
\text { personal or professional fulfilment }\end{array}$ \\
\hline Skills & $\begin{array}{l}\text { The need of learning how to become an } \\
\text { entrepreneur }\end{array}$ & $\begin{array}{l}\text { Capacity to analyze, plan, organize, manage, delegate, } \\
\text { debrief, evaluate and record related actions }\end{array}$ \\
\hline Attitude & $\begin{array}{l}\text { The need of learning to become } \\
\text { entrepreneurial }\end{array}$ & $\begin{array}{l}\text { Being pro-actively focused, taking responsibility for } \\
\text { own learning, career and life }\end{array}$ \\
\hline
\end{tabular}

Tab. 2. The Corporate Social Responsibility (CSR) core principles, after ISO 26000 (2010)

\begin{tabular}{ll}
\hline The principle & Core aspects \\
\hline Accountability & To be accountable for the impacts on society and the environment \\
\hline Transparency & To make decisions that impact on society and the environment, transparently \\
\hline Ethical behavior & To behave ethically at all times \\
\hline $\begin{array}{l}\text { Respect for stakeholders } \\
\text { interests }\end{array}$ & To respect, consider and respond to the interests of stakeholders \\
\hline Respect for the rule of law & To accept and mandatory respect the rule of law \\
\hline $\begin{array}{l}\text { Respect for international } \\
\text { norms of behavior }\end{array}$ & To respect international norms of behavior \\
\hline \begin{tabular}{l} 
Respect for human rights \\
\hline
\end{tabular} & $\begin{array}{l}\text { To respect human rights and recognize both their importance and } \\
\text { universality }\end{array}$ \\
\hline
\end{tabular}


social responsibility is seen as "the responsibility of enterprises for their impacts on society" that asks for appropriate processes to integrate social, environmental, ethical, human rights and consumer concerns into the enterprise business operations. Thereby, a properly application of the concept requires a clearly understanding of the key principles that lead to the social responsibility behavior, as it is depicted in table 2 (ISO 26000, 2010).

Developing and applying the entrepreneurial thinking within the current business market are closely related to the fundamental principles of social responsibility. These lead to designing properly business processes based on capturing and respecting the concern for human being and for the environment, with the aid of honesty, equity, integrity and a commitment to address business stakeholders' interests.

\section{RESULTS AND DISCUSSION}

Considering the abovementioned insights into the entrepreneurship and social responsibility, the authors considered beneficial to ascertain the main similarities and differences, as many of the practical problems arise from a poor understanding of the concepts (Tab.3).

The analysis in table 3 outlines that to be successfully implemented both concepts call for properly designed management processes as planning, organizing, managing, monitoring and controlling, and, also, improving processes. Consequently, running the processes on an efficiently bases needs the adequately assignment of human, technical and financial resources. Although, entrepreneurship is usually viewed as a matter of one's ability to take action, to successfully implement the entrepreneurial thinking into real practices requires a thorough understanding of the management processes needed to achieve objectives.

Worthy to be noted, the differences between the two concepts are referring to the level of impact, the concept boundaries and definition. The entrepreneurship covers the individual's relation to working circumstances whereas the social responsibility encapsulates the effects of organization on society and the environment. Moreover, the entrepreneurship concept is seen as a sum of attitudes, knowledge and skills which can be learned and developed, and the social responsibility is defined as a collection of principles, policies and practices which have to be known, understood and, most important, respected.

In this regard, the authors have modeled the relationship and proposed an integrative model that encapsulates the relationship arisen from the entrepreneurial thinking and the social responsibility of the businesses to act and

Tab. 3. The comparative analysis of entrepreneurship and social responsibility, developed by authors

\begin{tabular}{lll}
\hline Similarities & Entrepreneurship & Social responsibility \\
\hline Performed by & Individuals & Individuals \\
\hline Acquired and develop & By entrepreneurship education & By social responsibility education \\
\hline Implemented by & $\begin{array}{l}\text { Management processes: planning, } \\
\text { organizing, managing, monitoring and } \\
\text { controlling, improving processes }\end{array}$ & $\begin{array}{l}\text { Management processes: planning, } \\
\text { organizing, managing, monitoring and } \\
\text { controlling, improving processes }\end{array}$ \\
\hline Resources required & Financial, technical and human resources & $\begin{array}{l}\text { Financial, technical and human } \\
\text { resources }\end{array}$ \\
\hline Differences & Entrepreneurship & Social responsibility \\
\hline Aim & To turn ideas into actions & To ensure a health eco-system \\
\hline Level of impact & Individual & Organizational \\
\hline Concept boundaries & The relationship between individual and & $\begin{array}{l}\text { The relationship between organization } \\
\text { his working environment its impact on environment }\end{array}$ \\
\hline Concept definition & A sum of attitudes, knowledge and skills & $\begin{array}{l}\text { A sum of principles, factors and } \\
\text { conditions }\end{array}$ \\
\hline
\end{tabular}

Integrated impact: A sustainable development of the knowledge base society 
behave in a way that contributes to a sustainable development of the society (Fig. 1).

The originality of the model proposed emerged from mapping out the connections between two levels of analysis: conceptual and practical, related to the entrepreneurship and social responsibility concepts. Both analysis levels are required to be known and understood in order to assure the ongoing viability of business creation.

The conceptual level answers to the question "What?" and has different bonds depending on the concept in question. For entrepreneurship concepts, the question is "What should be the knowledge, skills and attitude for an entrepreneur in order to create new business?", whereas for social responsibility concept, the question is "What should be the core principles for an entrepreneur in order to behave responsible?".

As the proposed model suggests, creating innovative businesses entails an entrepreneurial mindset consisted of sense of initiative, creativity, innovation capacity and risk taking. Moreover, to ensure the ongoing viability of any innovative business, which is a major necessity for the development of the society, the expectations of stakeholders regarding the business performance has been changing over the past decades. Globalization, environmental and health issues, growing economic and financial interdependence and more geographically dispersed value chains have formed the context for social responsibility expectations of societies around the world, defined by the core principles: human rights, labor practices, the environment, fair operating practices, consumer issues, and community involvement ISO 26000 (2010) .

The practical level answers to the question "How to put in practice the conceptual level?". The answers are different depending on the subject in question. For the concept of entrepreneurship, which means to turn ideas into actions, it is needed a properly defined coordination mechanism that enables individuals to define specific objectives, organize required resources, monitor and control

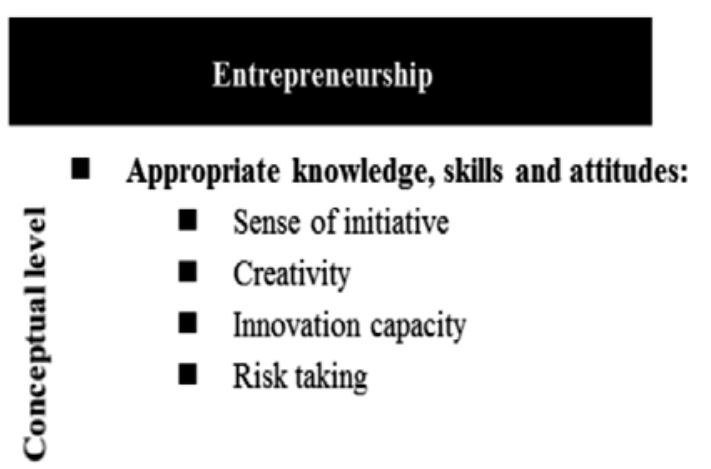

Social responsibility

Appropriate principles and core subjects:

- Human rights

- Labor practices

- The environment

- Fair operating practices

- Consumer issues

- Community involvement and development

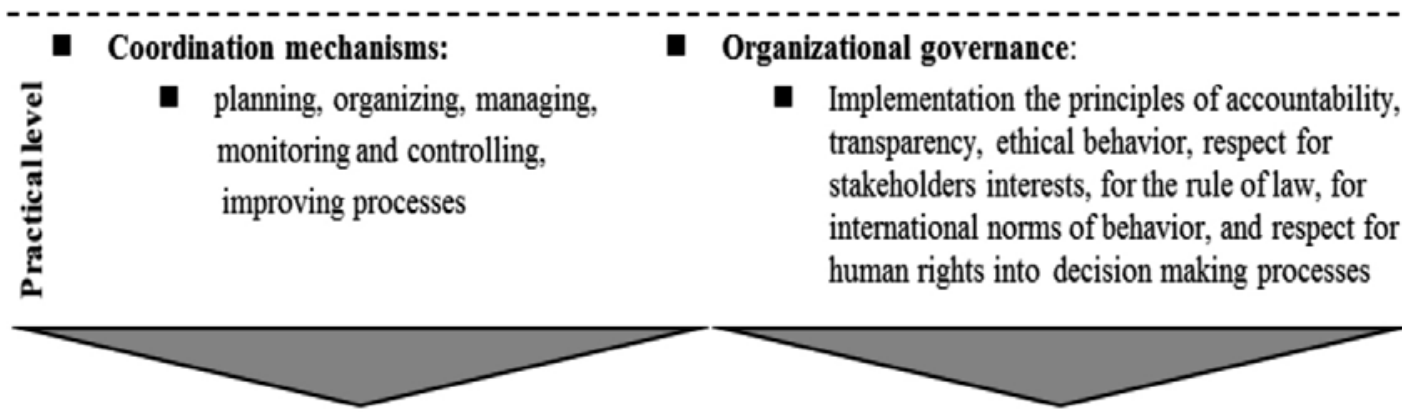

Contributing to commercial and social activities, innovative business

Contributing to improved concern on society and the environment

Healthy personal, professional, social life; Sustainable development; Eco-Inovation in Business Market

Fig. 1. The model of entrepreneurship and social responsibility, proposed by the authors 
the results and progress, and indubitable, to apply corrective and preventive actions to bring actual work results in line with expected performance. For the concept of social responsibility, which means to consider all principles holistically throughout their interdependences, it is needed a properly designed organizational governance that assures an effective decision making and implementation system.

Considering the work of Van de Ven et. all (1984) that taken into consideration the individual, organizational and societal levels, the authors propose an integrative model considering the conceptual and practical aspects of entrepreneurial thinking in conjunction with social responsibility concern.

Moreover, the authors take advantage of the research findings argued by Duening et. all (2010) that highlight the necessity of social obligation, social reaction, and social responsiveness for business practices. The elements embedded in conceptual and practical levels of entrepreneurship as well as social responsibility will lead to the ongoing viability or sustainability of any specific business/enterprise. The entrepreneurship has to be closely related to the objective of social responsibility of enterprise which means to achieve sustainability for society, based on addressing social, economic and environmental aspects in an integrated manner.

For these reasons, the model proposed highlights the need of the cross-disciplinary tackle of entrepreneurship and social responsibility, being a bridge towards gaining sustainable use of resources and sustainable livelihoods related to the sustainability of society.

\section{CONCLUSION}

Although, the analysis' boundary is limited to the conceptual investigation, the study attempts to ascertain the inner connections in terms of similarities and differences between entrepreneurship and social responsibility concepts. The authors proposed a conceptual model that emphasizes the complex cognitive and attitudinal mechanisms related to entrepreneurial thinking needed to turn ideas into actions and to create innovative businesses. The model incorporates the responsibility of any business, enterprise or organization to society and the environment by designing related processes and structures conducive to social responsibility practicing.

Finally, the authors paid attention to the overarching role of social responsibility in achieving high business performance, since the business world has become increasingly aware of the need for and benefits of social responsibility behaviour that contribute to the development of the economic, environmental and social dimension of peopleđs life.

\section{REFERENCES}

1. Casson M (1982). The entrepreneur: An economic theory. Barnes \& Noble books Publishing, Totowa, Ney Jersey.

2. Council Recommendation 394, (2006). The Key Competences for Lifelong Learning - A European Frameworks. An annex of a Recommendation of the European Parliament and of the Council of 18 December 2006 on key competences for lifelong learning (EC) No 962/2006. Official Journal of the European Union (L394): 1-18. Available at: http://eur-lex.europa.eu/LexUriServ/ site/en/oj/2006/1_394 /__39420061230en00100018. pdf. Accessed 2014 Aug. 4.

3. Duening TN, Hisrich R, Lechter M (2010). Technology entrepreneurship: Creating, capturing, and protecting value. Elsevier Academic Press, London.

4. European Commission (2010). Communication from the Commission. Europe 2020. A strategy for smart, sustainable and inclusive growth, COM (2010) 2020 final. Brussels: 1 - 35. Available at: http://eur-lex.europa. eu/LexUriServ/LexUriServ.do?uri= COM:2010: 2020: FIN:EN:PDF. Accessed 2014 Aug. 5.

5. European Commission (2011). A renewed EU strategy 2011-14 for Corporate Social Responsibility. Communication from the Commission to the European Parliament, the council, the European Economic and Social Committee and the Committee of the Regions, COM(2011) 681 final. Brussels: 1-15. Available at: http://eur-lex.europa.eu/LexUriServ/LexUriServ. do?uri=COM:2011:0681:FIN: EN:PDF. Accessed 2014 Aug. 18.

6. European Commission (2012). Directorate - General for Enterprise and Industry. Flash Eurobarometer Report 354. Entrepreneurship in the EU and beyond. Brussels: 1 - 256. Available at: http://ec.europa.eu/public_opinion/ flash/fl_354_en.pdf. Accessed 2014 Aug. 5.

7. European Commission (2012). Directorate - General for Enterprise and Industry. Effects and impact of entrepreneurship programmes in higher education. Brussels: 1- 87. Available at:http://ec.europa.eu/ enterprise/policies/sme/promoting-entrepreneurship/ education-training-entrepreneurship/higher-education/ index_en.htm. Accessed 2014 Aug. 18.

8. European Commission (2013). Directorate - General for Enterprise and Industry. Flash Eurobarometer Report 363. How companies influence our society: Citizen View. Brussels: 1 - 134. Available at: http://ec.europa.eu/ 
public_opinion/flash/fl_363_en.pdf. Accessed 2014 Aug. 5.

9. ISO/DIS 26000:2010, (2010). Guidance on social responsibility. Available at: https://www.iso.org/ obp/ ui/\#iso:std:iso:26000:ed-1:v1:en. Accessed 2014 Jun. 5.

10. MacClelland DC (1967). The Achieving theory. A Free Press Paperback, Macmillan Publishing Co., New York.

11. Matlay H (2005). Researching entrepreneurship and education part 1: what is entrepreneurship and does it matter? in the Education and Training J. 47 (8/9): 665677.
12. Matlay H (2006). Researching entrepreneurship and education Part 2: what is entrepreneurship education and does it matter in Education and Training J. 48 (8/9): 704718.

13. Shane SA (2003). A general theory of entrepreneurship: the individual - opportunity nexus. Edward Elgar Publishing, Cheltenham, UK.

14. Van de Ven AH, Hudson R, Schroeder R (1984). Designing new business start-ups: Entrepreneurial, organizational, and ecological considerations in Journal of Management 11: 87- 107. 